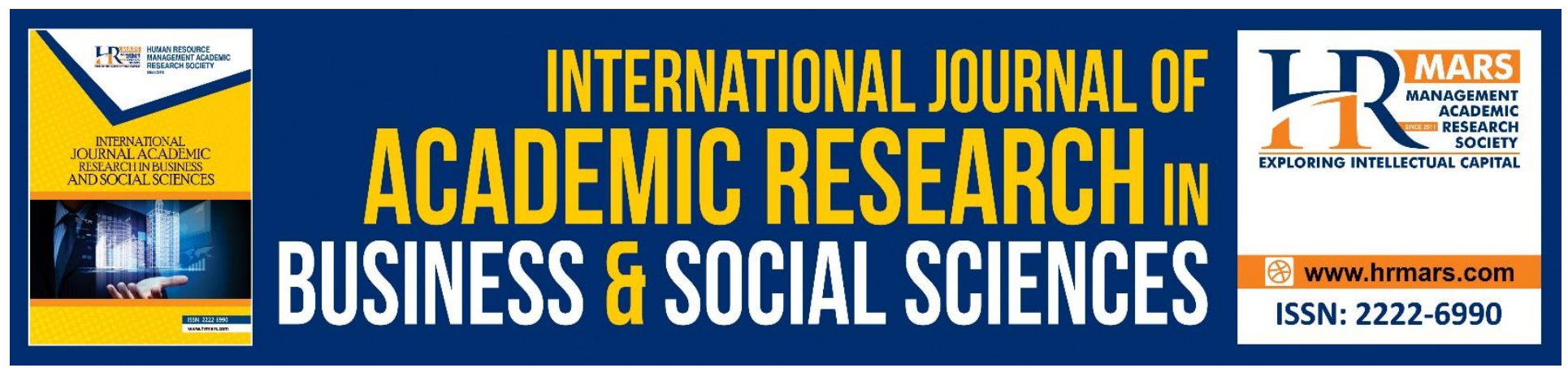

\title{
Constructivism Learning Environment by Using Augmented Reality in Art History Course
}

\author{
Nurziehan Binti Baharuddin, Hafizah Rosli, Mohd. Suhaimi Juhan
}

To Link this Article: http://dx.doi.org/10.6007/IJARBSS/v10-i8/7497

DOI:10.6007/IJARBSS/v10-i8/7497

Received: 03 May 2020, Revised: 09 June 2020, Accepted: 20 July 2020

Published Online: 19 August 2020

In-Text Citation: (Baharuddin, Rosli, Juhan, 2020)

To Cite this Article: Baharuddin, N. B., Rosli, H., Juhan, M. S. (2020). Constructivism Learning Environment by Using Augmented Reality in Art History Course. International Journal of Academic Research in Business and Social Sciences. 10(8), 13-25.

Copyright: (C) 2020 The Author(s)

Published by Human Resource Management Academic Research Society (www.hrmars.com)

This article is published under the Creative Commons Attribution (CC BY 4.0) license. Anyone may reproduce, distribute, translate and create derivative works of this article (for both commercial and non-commercial purposes), subject to full attribution to the original publication and authors. The full terms of this license may be seen at: http://creativecommons.org/licences/by/4.0/legalcode

Vol. 10, No. 8, 2020, Pg. 13 - 25

http://hrmars.com/index.php/pages/detail/IJARBSS

JOURNAL HOMEPAGE

Full Terms \& Conditions of access and use can be found at http://hrmars.com/index.php/pages/detail/publication-ethics 


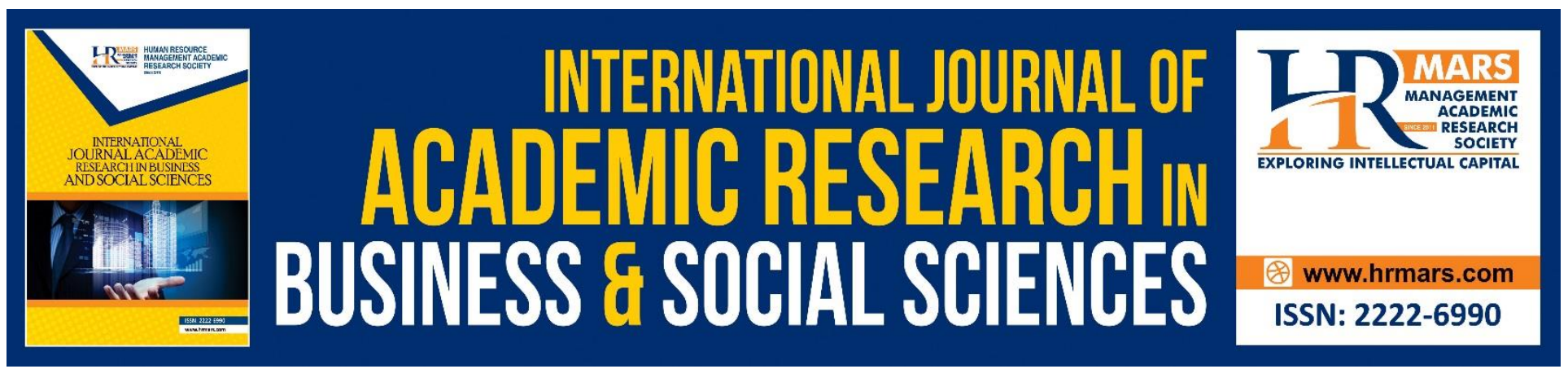

\title{
Constructivism Learning Environment by Using Augmented Reality in Art History Course
}

\author{
Nurziehan Binti Baharuddin \\ Faculty of Film, Theatre and Animation (FiTA), Universiti Teknologi MARA (UiTM), Puncak Perdana \\ Campus, Malaysia \\ Email: nurziehan@uitm.edu.my \\ Hafizah Rosli \\ Faculty of Film, Theatre and Animation (FiTA), Universiti Teknologi MARA (UiTM), Puncak Perdana \\ Campus, Malaysia \\ Email: hafizahrosli@uitm.edu.my \\ Mohd. Suhaimi Juhan \\ Faculty of Film, Theatre and Animation (FiTA), Universiti Teknologi MARA (UiTM), Puncak Perdana \\ Campus, Malaysia \\ Email: suhaimijuhan@uitm.edu.my
}

\begin{abstract}
Augmented Reality $(A R)$ is a potential new aid in education as it has the ability to enhance student engagement towards the content of any subject. The computer technology in AR allows the users to combine the physical and the virtual world. The involvement of AR in higher education is widely researched and rapidly evolved but underutilised. Teaching history courses with the conventional method in a class can be very challenging, especially to get the student engagement. The conventional method used in class not only limits the student reception and comprehension but also made them into passive students. Learning through AR results in functional knowledge transfer to students as it includes exploration of practical and theoretical knowledge. This research aims to examine student engagement in learning animation history course by using AR. Qualitative method was used by approaching the students of animation history as the focus group in order to examine their engagement, attention, and interest based on Constructivism Learning Theories. As a result, AR enhances student engagement in Art History class, through active and constructive learning. The digital content in AR improves the learning condition as well as promotes and supports exploratory behaviour with multiple modes of presentation such as textual information assisted with video and audio, 3D interactivity, peer interaction and coaching.
\end{abstract}

Keywords: Augmented Reality, Mobile Learning, Student Engagement, Constructivism Learning. 
INTERNATIONAL JOURNAL OF ACADEMIC RESEARCH IN BUSINESS AND SOCIAL SCIENCES Vol. 10, No. 8, 2020, E-ISSN: 2222-6990 @ 2020 HRMARS

\section{Introduction}

The rapid changes in Malaysia national education system in the 1980s have transformed the curriculum structure of history subject in school. History subject can be categorized under Social studies, which also include geography, sociology, psychology, philosophy, economics and law. Social studies aim to make students gain knowledge about their past, present, and future and understand human connections as well as their responsibilities as a citizen (Ulusoy \& Gulum, 2009). Therefore, the Ministry of Education Malaysia (MEM, 2002) has acted proactively through the Education Development Master Plan (PIPP) 2006-2010 by placing the subject as a benchmark to develop citizen from early schooling with characteristics of patriotism and love the country and unity through the understanding of history curriculum. Teaching history is essential for the unity of Malaysia's state and national culture as it helps students to be aware of the past events. History subject is critical in the social studies curriculum to ensure cultural unity can be passed over to the future generation. Besides, history will teach students various skills that will help them to set up relationship between the past, present, and future, make realistic comments and more successful options in their social lives (NME, 2006). History courses usually set specific goals, which to initiate students to comprehend the general concept of historical theme, elevate skills in critical thinking and understand the importance of the historical project throughout collecting evidence and argumentation. It has been a challenge for most educators to accomplish these goals as the large size class limits the lecturers to provide a vast range of materials and it is difficult to communicate and interact face to face with the students (Harbison \& Waltzer, 2013). Thus, most educators preferred to have practical training consist of small groups, where the students can discuss, research and write on the particular topics. Furthermore, getting students engagement can be challenging if the same conventional method is used in the classroom. Therefore, this research aim is to discover students' engagement in FTA412 Animation History class in Faculty of Film, Theatre \& Animation, Universiti Teknologi MARA, Malaysia by using Augmented Reality (AR) through Constructivist Learning Theory

In normal circumstances, conventional methods of teaching were usually used where instructions were given and learning activities were all arranged and delivered by the teacher (De Freitas et al., 2010; Liu, 2010). Learning materials were mostly based on inactive material such as textual information (Chao \& Chen 2009; Taketa et al., 2007), which did not include any motion movement (Craig \& Grath, 2007; Kuhl et al., 2011). As the world of technology shifted, educators try to get away from using the same conventional method of teaching but combining conventional text and multimedia. The common and usual history textbook contains pictures, diagrams, paintings, timelines and charts narratively to suggest the historical events and facts. Under the normal circumstances, lecturers will provide documentaries and films of the historical events to enhance their understanding of the subject matter. Other multimedia tools such as animated presentations, YouTube videos, or online forums used in class in order to get student's engagement in Art History class. This constructive method proposes that learning the tangible form of study leads to a better understanding of the subject matter rather than learning through lecture or memorisation. Students are offered with more information from a variety of sources and viewpoint rather than getting limited information from what is in the textbook. However, the sense of multimedia needs to be broadened as the rapid changes in the world of technology give more platforms to gather and present the information. 
INTERNATIONAL JOURNAL OF ACADEMIC RESEARCH IN BUSINESS AND SOCIAL SCIENCES Vol. 10, No. 8, 2020, E-ISSN: 2222-6990 @ 2020 HRMARS

The objectives of this study are

1) To examine the use of augmented reality in art history course through constructivism learning environment.

2) To analyse the student understanding through augmented reality in art history course through constructivism learning environment.

\section{Augmented Reality}

Augmented reality is a new technology development that has been discussed widely as it has a great potential in business, entertainment, education and more. AR usually use advance camera and sensor technology via smartphones, or tablets and assist users to interact with digital information entrenched within the physical setting. Currently, there are two forms of AR available to instructional designers; location-based and vision-based. GPS-enabled smartphones and tablets are influenced by location-based AR to present digital media to users as they move over a physical area. The media (i.e., texts, graphics, audio, videos, 3D models) are elicited and oriented through GPS and compass technologies to boost the physical setting with story, navigation, or information relevant to the location. Contrary to location-based AR, vision-based or target-based AR depicts digital media to consumers after they point the camera in their mobile device at an object or target (e.g., QR code, 2Dtarget) (Dunleavy, 2014).

The evolution of $A R$ is rapidly growing and is still at the beginning phase. However, there are a lot of studies have been done and the technology keeps on evolving. AR is different than virtual environments (VE) or known as virtual reality (VR) where environment in VR created solely in the computer. AR combines the real-world environment with computer-generated imagery. AR technology helps users to hear, see, feel and interact with surroundings differently (Krevelen \& Poelman, 2010). Figure 1 below shows the concept of augmented reality and its relation between virtual and physical world.

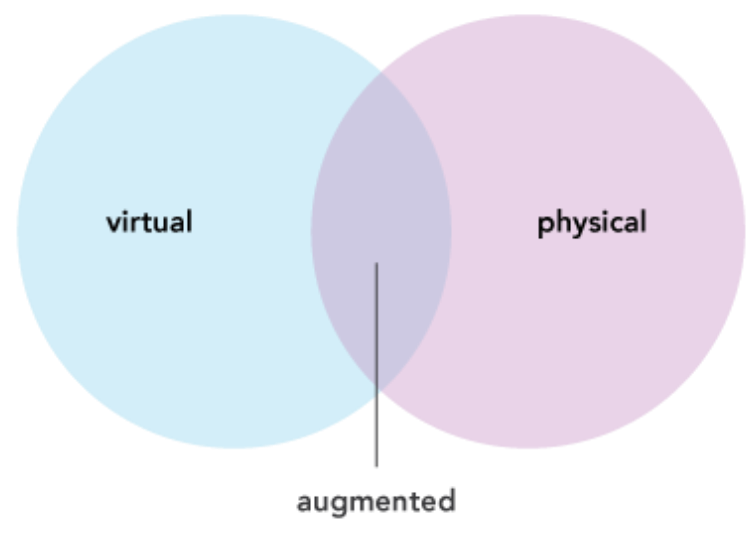

Figure 1: Concept of Augmented Reality 
INTERNATIONAL JOURNAL OF ACADEMIC RESEARCH IN BUSINESS AND SOCIAL SCIENCES Vol. 10, No. 8, 2020, E-ISSN: 2222-6990 @ 2020 HRMARS

\section{Augmented Reality in Education}

Aligned with the Industrial Revolution 4.0, technology becomes a part of our lives and changed the way of the society think and pertain information. This also affects the education world, where technology has opened new platform for teaching and learning process and shifted into new level. AR technology application has been emerging in educational market for its ability to connect gaps and bring more solid approach in education. The involvement of virtual and real-world experience enhances student-centred activities (Antonioli et al., 2014). Previous research conducted by Oh \& Byun (2012) presents AR learning apps allow students to experience interactive flower gardening by targeting the marker on the textbook. Students are able to interact with digital object build in the AR apps and relate with the real environment. The students were given specific task to accomplish and have to decide on a suitable simulation to be applied on the augmented flower. They were provided with proper guidelines and were encouraged to solve problems while completing the given task.

In 2006, Wagner et al. developed an educational-based collaborative handheld game named Virtuoso for learning the history of art. This game expected to deal with an accumulation of works of art as indicated by their creation date alongside a course of events, in three distinct conditions: cards, a PC and a PDA. The participant was instructed that their objective was to acquire a high group score instead of an individual score to increase the level of collaboration, (Wagner et al., 2006). There is a real need for teachers or instructional designers to design learning activities for AR (Kesim \& Ozarslan, 2012). Scholars have classified three different learning approach and characteristics, which emphasise on engaging learners in different roles, learner's interaction with physical locations and the design of learning task (Wu et al., 2013). AR applications provided some of these characteristics by giving opportunity for learners to interact with physical location and designing interactive learning tasks. Different researchers have utilized interaction with mixed reality application for learning physics and showed that both learning and affective engagement were improved because of the design application (Lindgren et al., 2016). According to Schrier (2006), AR games designed with affective pedagogy such as self- directed or task-based learning can motivate and strengthen the practice of skills as well the problem-solving skill.

\section{Constructivism Theory of Learning}

Constructivism theory can be defined as a learning process based on own experience and constructive individual interpretation on the courses learned. It is a theory based on scientific studies of how people learn. Constructivists believe that knowledge are derived from the meaning and own understanding through experiencing things and reflecting the experience (Bereiter, 1994). Constructivism is usually used to display student's level of understanding into higher level of thinking (Myududu et al., 2012). Students are encouraged to explore, experiments, asking questions and solving problems to gain more knowledge. The students then, need to reflect and discuss their understanding of the course. The instructor usually guided the student's ideas and activities to build the understanding in their mind (Oliver, 2000)

Constructivists suggested that human learning is constructed where previous experience and learning helps learner to develop new knowledge. Educators need to understand this principle and should considers students' knowledge by allowing them to put their knowledge into practice (Mvududu et al., 2012). However, educators need to break the consistencies of students' current knowledge by 
providing new environment and experience in order to allow them to use different methods and thinking. Constructivism will benefit students by inspiring them to understand and learn independently, enhance their critical thinking, and to motivate them. Constructivism learning is obviously contrast with the usual learning practice, where the reception and passive transmission of information usually occur from one individual to another (Bada \& Olusegun, 2015).

Early learning theories of formal instructional design usually derived from the objectivist theory. Objectivist theory is based on the work of behaviourist such as Skinner (1953) where objectivists believe that knowledge interpretation by individuals has objectives and has reliable set of facts, and to be correct or incorrect. Objectivists believe in order to learn something, the course must consist of facts, formulas, principals or theories. Hence constructivism is often compared to objectivism, as these two theories are totally opposite (Bada \& Olusegun, 2015). In constructivism learning theory, creating learning environment that gives exposure to the material being studied is important. Hence, by experiencing the material directly, the students will learn the meaning behind the subject matters and promotes more effective learning. One of the principles of all constructivism learning is that it has to be an active process (Tam, 2000); thus, the opportunity for active learning in any constructivism-learning environment must be provided.

\section{Methodology}

This research paper uses triangulation method in observing qualitative data. The triangulation method involves collecting the data for analysis process. A focus group of 10 students in Animation History class involved as observing the student engagement, attention and interest base on. Finding of the study will be gathered through analysing the constructivism learning theory with observation and data collection. Students need to scan the QR code given and download an app named AAREAL. The students were being observed based on their engagement through the constructivism learning theory. Based on the triangular method, each evaluator will compare the findings to develop more understanding on how the evaluators view the issue (Guion, 2002).

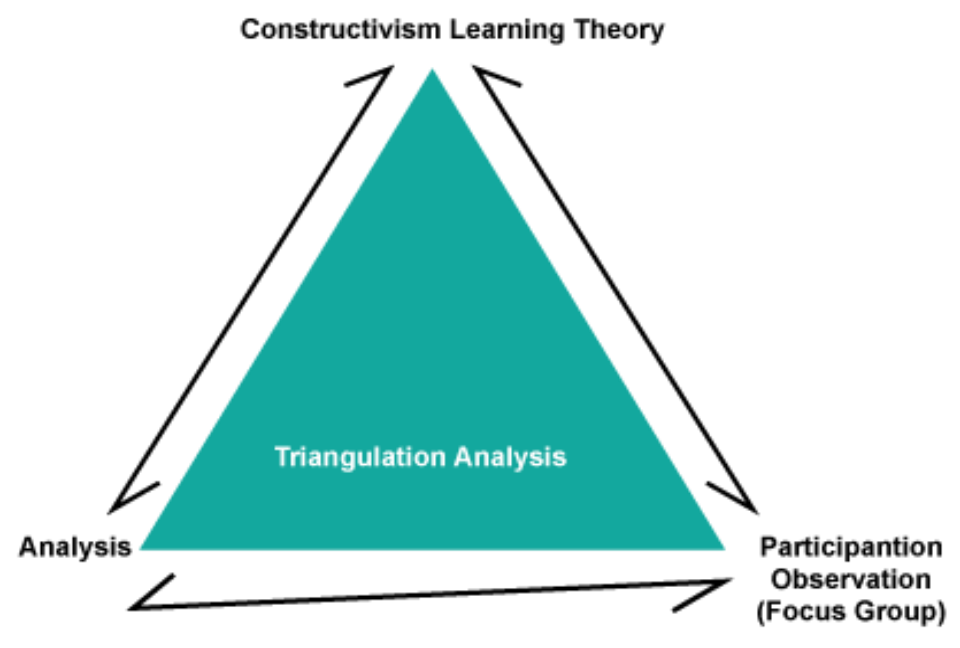

Figure 2: Triangulation method 
INTERNATIONAL JOURNAL OF ACADEMIC RESEARCH IN BUSINESS AND SOCIAL SCIENCES Vol. 10, No. 8, 2020, E-ISSN: 2222-6990 @ 2020 HRMARS

\section{Finding and Discussion}

\section{AAREAL Concept and Development}

AR can be described as application of technologies that enhance a physical space or object with relevant information presented in a digital medium (Dunleavy, 2014; Klopfer \& Sheldon, 2010). Technology advancement enhance the potential of AR, thus gives opportunity for learning experience to expand where AR not only represent the merging of hardware, software, and relevant information. AR can be best defined as a concept when it is applied in education where it is more than only combining specific technologies ( $\mathrm{Wu}$ et al., 2013). Wide range application can be utilised from hardware, software to design strategies (Chang et al., 2013), in order to develop a new concept that give astounding AR learning experience.

On the other hand, AAREAL is a mobile app, which integrates AR and promotes active learning for Animation History course. AAREAL was developed with Unity software where all information such as texts, visuals, audio, and videos were gathered in one platform. During the implementation of AAREAL project, students were equipped with Internet-connected mobile devices and text handouts. When students pointed to the marker, augmented information triggered by an image and presented to learners on the mobile device. The media presented is designed to enhance students' understanding of specific topics in the history of animation as well as to get their engagement in particular topic. AAREAL is unique on its own; it connects physical forms and digital space and provides tremendous teaching and learning experience in class. AAREAL also works on printed materials as well as computer screens. The learning materials in AAREAL can be regularly updated according to current content and information. Figure 3 below shows the combination of conventional notes and AAREAL apps.

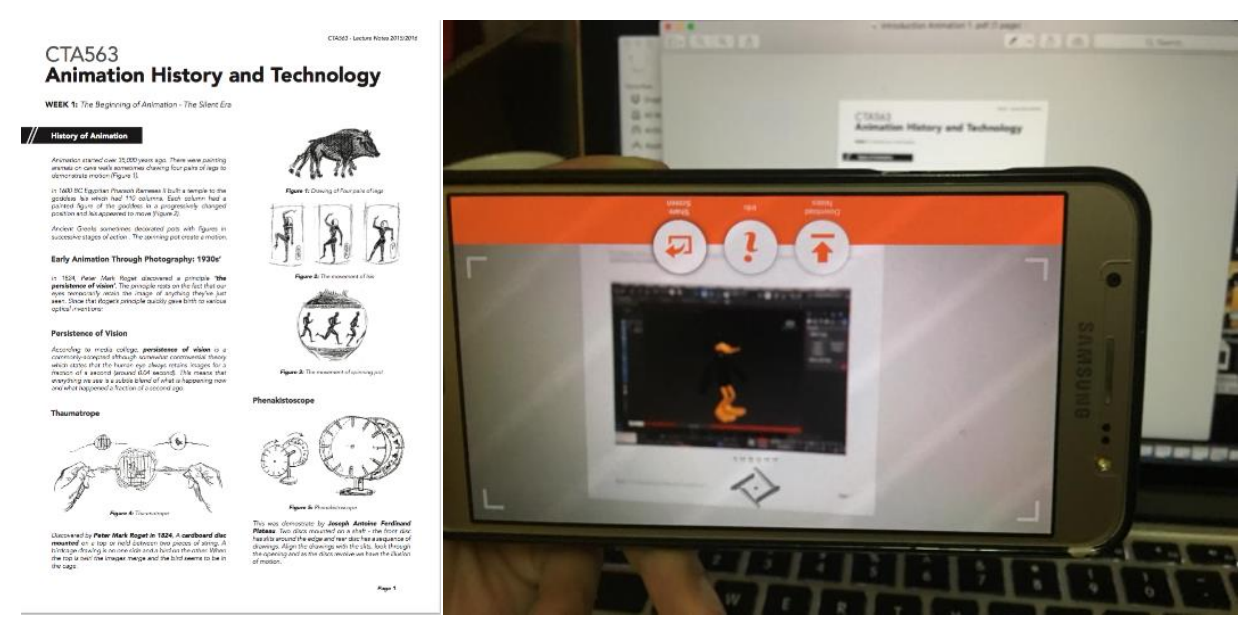

Figure 3: Conventional notes and AAREAL interface

\section{Discovery}

Video with audio was embedded in AAREAL to assist textual information in order to enhance students understanding of the subject matter. Constructive learning theories usually require students to explore the information rather than memories textual contents. By using 3D interactivity, AAREAL allows students to participate and navigate objects in the real world. For example in figure 4, Zoetrope; an early device to work along with persistence of vision, however, is hard to be found. By creating interactive 3D Zoetrope, students not only know the form of the object but also able to 
interact with it. Besides that, the digital contents improve the learning condition as well as promote and support exploratory behavior. Students are free to explore objects from the past and to learn historical events through video and 3D interactivity.

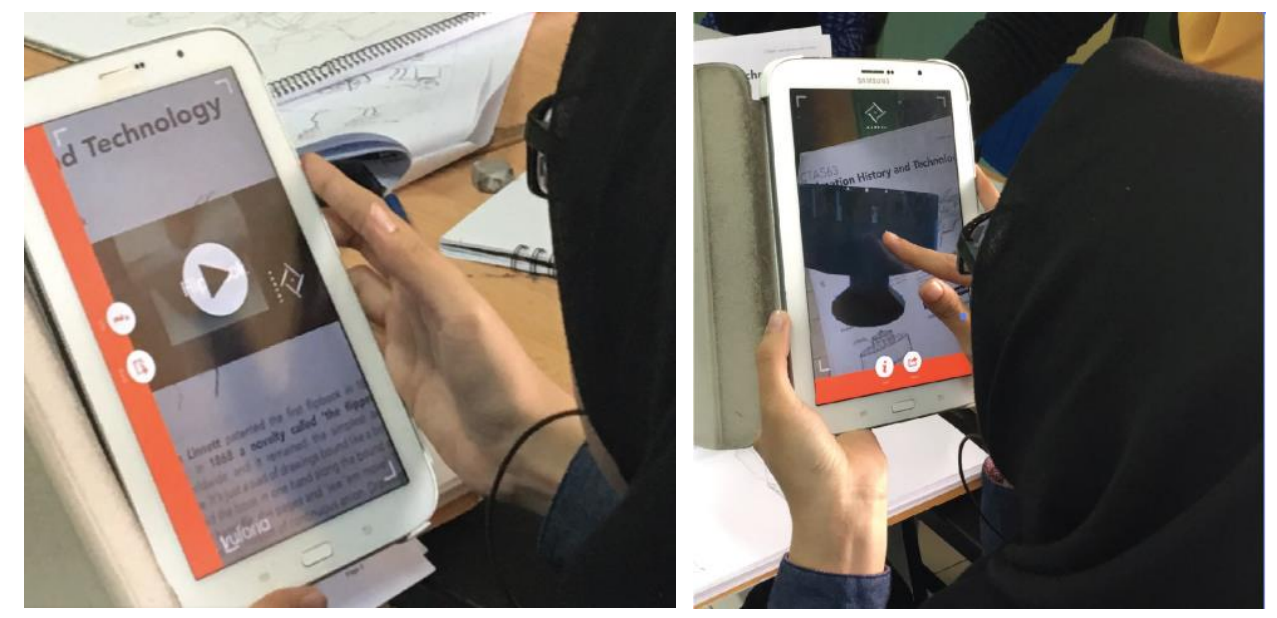

Figure 4: Participants exploring AAREAL contents

\section{Collaboration}

Promoting social collaboration among students and teachers are important in constructive learning theory. According to Kaufmann (2013), AR allows multiple users to access and share the same space virtually while staying grounded in real world. This is a powerful technique for educational purposes as the users not only communicate through gestures and speech but can also be mixed with textual conversation or remote collaboration. AAREAL allows users to screen shot the learning activities share their experience and discussion through social media. This encourages the concept of learning and sharing especially among peers.

\section{Scaffolding}

Result of the focus group of Art History students indicate they are well engaged with the integration of mobile apps through AR. Scaffolding is a teaching strategy that enhances, encourages and enables students to learn and helps them implement constructivism learning environment in the classroom. Scaffolding helps students to become independent learners, problem solvers and self-regulated. It also facilitates the ability of students to build on previous knowledge and helps them to internalise new information. As the scaffolder, lecturers use various concepts, materials, tools and technologies to support the learning activities of the students. It can be used between lecturer and student at any point of interaction (Joshi, 2019). For example in AAREAL, students with the help of scaffolder (lecturer), need to study the conventional notes given in class and use AR to experience the 360' visual representation of animation history content. This helps the students to explore and relearn the previous knowledge in interactive way, which encourage their independent and self-learning. This scaffolding (mobile apps) helps every student to actively involve and give them the opportunity to progress faster. Together with the opportunity to progress at a slower pace, weak students get better attention. Scaffolding teaching strategy has mainly three features: contingency, fading, and transfer of responsibility (Joshi, 2019). In contingency, as the scaffolder, the lecturer continually evaluates the performance of the students and provides adequate support in specific tasks through the current 
INTERNATIONAL JOURNAL OF ACADEMIC RESEARCH IN BUSINESS AND SOCIAL SCIENCES Vol. 10, No. 8, 2020, E-ISSN: 2222-6990 @ 2020 HRMARS

strengths and weaknesses of the students in handling textual information.

In AAREAL apps, students can experience 3D or $360^{\circ}$ of animation instruments in detail compared to conventional visual representation in a lecture notes or books. In fading, the lecturer gradually withdraws the scaffolding, as students are able to perform tasks independently at a certain point in time. This is the stage where support for teachers is no longer needed. Through the apps, students were required to do an assignment and discuss with peers independently and share their discussion in social media like Facebook page. As a result, students will be more confident and try to solve their learning problems independently. Through the transfer of responsibility, the responsibility of performing tasks slowly transferred from lecturer to students, which is referred to students' cognitive and meta-cognitive activities. In 1956, Benjamin Bloom created a classification system for cognitive skills and learning behaviour that is now referred as Bloom's Taxonomy. It contains six cognitive levels of complexity, which is knowledge, comprehension, application, analysis, synthesis, and evaluation. Through this focus group, students learned from these mobile apps as a scaffolding to answer the quiz and final exam. As a result, student's examination results were increased in previous semester.

\section{Self-Guided}

Self-guided or self-directed learning is an essential skill to be acquired for the promotion of life-long learning. In (Sze-Yeng \& Hussain, 2010) study, they argued that the course supported a studentcentred and self-directed approach by integrating technological, pedagogical and content knowledge as web technology platforms such as online discussion forums for Moodle, Google Docs and Wikispaces empowered adult participants with self-directed learning. Nevertheless, AAREAL apps applied life long-learning system as students learn to experience by their own and solve the tasks or problems of assessments independently.

Self-guided had a connection with scaffolding, and it works together in constructivist learning environment. The use of AAREAL as the central learning space encourages initiative and autonomy in exploring the instruments of animation, videos and discussion as added knowledge and extends selfdirected learning. For example, self-directed learning with guided comments from peers and lecturers are exchanged within AAREAL mobile apps. To promote self-directed learning, learners were given a choice to identify and formulate their personal learning goals such as to identify the relevance and their interest on the subject matter. The students also have to choose and implement appropriate learning strategies and to evaluate their learning outcomes. This mutual sharing session is an instructional strategy to promote equal power sharing in the classroom. Through this focus group, it improves the problem of 'spoon feed' habit among students and increases students' effort to work independently for their assignments.

\section{Difference between Traditional Classroom and Augmented Reality Classroom}

Focus in constructivist classroom has been shifted from the teacher to the students. Passive students no longer receive direct information from the teacher, which normally seen as the expert, who just wait for them to be fed. In the constructivist model, students are advised to be actively involved in their own learning process. The functions of teacher are to facilitate, coach, resolve, encourage, and assist students to grow and assess their thought, and their learning. In the constructivist classroom, both teacher and students think of dynamic, realistic and explorative world, not as mind-numbing subjects to be memorized. 
INTERNATIONAL JOURNAL OF ACADEMIC RESEARCH IN BUSINESS AND SOCIAL SCIENCES Vol. 10, No. 8, 2020, E-ISSN: 2222-6990 @ 2020 HRMARS

Table 1 below compares the traditional classroom to the constructivist learning classroom, which applied augmented reality in classroom by using AAREAL app as one of the mediums of teaching and learning for Animation History course. Significant differences can be seen in basic assumptions about knowledge, students, and learning.

\begin{tabular}{|c|c|}
\hline oom & AR Classroom \\
\hline $\begin{array}{l}\text { Curriculum begins with the parts of } \\
\text { the whole. Emphasizes basic skills. } \\
\text { This method of teaching progresses } \\
\text { step by step, which emphasizes the } \\
\text { basic skills and knowledge, before } \\
\text { going into further details and specific } \\
\text { scope of learning. }\end{array}$ & $\begin{array}{l}\text { Curriculum emphasises big concepts, beginning with the } \\
\text { whole and expanding to include the parts. } \\
\text { This technique gives general ideas about the course as a } \\
\text { whole. After that, teachers will go into details, after students } \\
\text { get the idea about what the course is. } \\
\text { In Animation History course created in AAREAL, students are } \\
\text { able to download the app and get to know the whole idea } \\
\text { about the course by studying and exploring the content. This } \\
\text { explorable app contributes to exploration of the app and } \\
\text { allows students to discover the general idea about the whole } \\
\text { course, before the teacher get into details about it through } \\
\text { the module. }\end{array}$ \\
\hline $\begin{array}{l}\text { Strict adherence to fixed curriculum is } \\
\text { highly valued. } \\
\text { Nothing can change the curriculum. } \\
\text { Teachers and students have to follow } \\
\text { the structure of the module, causing } \\
\text { it a one-way learning process. }\end{array}$ & $\begin{array}{l}\text { Pursuit of student questions and interests is valued. } \\
\text { AAREAL encourages students to be more active and } \\
\text { interactive towards the content of the course. This app } \\
\text { enables students to share their thoughts regarding their } \\
\text { studies and knowledge through social media like Facebook } \\
\text { and Whatsapp. }\end{array}$ \\
\hline $\begin{array}{l}\text { Materials are primarily textbooks and } \\
\text { workbooks. } \\
\text { Conventional way of teaching and } \\
\text { learning always rely on book as the } \\
\text { primary source in this method, while } \\
\text { exercises mainly use workbooks to } \\
\text { enhance the knowledge of the } \\
\text { students. }\end{array}$ & $\begin{array}{l}\text { Materials include primary sources of material and } \\
\text { manipulative materials. } \\
\text { AAREAL is an interactive and manipulative tool to enhance } \\
\text { the student engagement in learning. It can be considered as } \\
\text { primary source of learning because it contains lecture notes. } \\
\text { AAREAL as well, contains manipulative augmented reality } \\
\text { interface for students to explore animation-related devices } \\
\text { which most of devices nowadays, are not available anymore } \\
\text { due to historical changes and factors. }\end{array}$ \\
\hline $\begin{array}{l}\text { Learning is based on repetition. } \\
\text { Students are required to memorise } \\
\text { the notes by repetitively to } \\
\text { understand the content. }\end{array}$ & $\begin{array}{l}\text { Learning is interactive, building on what the student already } \\
\text { knows. } \\
\text { This learning system is contradicted from the traditional } \\
\text { classroom. Students being taught to understand the basic } \\
\text { concept first. Through AR, students will further build up their } \\
\text { knowledge and skills over their basic understanding by using } \\
\text { the interactivity of AAREAL. }\end{array}$ \\
\hline $\begin{array}{l}\text { Teachers disseminate info } \\
\text { students; students are rec } \\
\text { knowledge. }\end{array}$ & $\begin{array}{l}\text { chers have a dialogue with students, helping students } \\
\text { struct their own knowledge. } \\
\text { h the emergence of digital communication and } \\
\text { inology, a new approach being used in order to construct }\end{array}$ \\
\hline
\end{tabular}


INTERNATIONAL JOURNAL OF ACADEMIC RESEARCH IN BUSINESS AND SOCIAL SCIENCES Vol. 10, No. 8, 2020, E-ISSN: 2222-6990 @ 2020 HRMARS

\begin{tabular}{|c|c|}
\hline $\begin{array}{l}\text { Only one-way learning process. } \\
\text { Teachers as presenter whilst students } \\
\text { as receiver. }\end{array}$ & $\begin{array}{l}\text { knowledge of students. AAREAL is used as a substance to } \\
\text { connect students with other students and teachers through } \\
\text { social media like Facebook and Whatsapp, by discussing any } \\
\text { related issues in knowledge sharing sessions. }\end{array}$ \\
\hline $\begin{array}{l}\text { Teacher's role is directive, rooted in } \\
\text { authority. } \\
\text { Teacher is dominant and has full } \\
\text { control towards students. }\end{array}$ & $\begin{array}{l}\text { Teacher's role is interactive, rooted in negotiation. } \\
\text { The learning system is more interactive, where students can } \\
\text { always interact each other through AAREAL app. Teachers } \\
\text { are not dominant anymore in class but will let students to } \\
\text { have their own learning time and exploring the topics before } \\
\text { they get to the teachers. } \\
\text { This kind of learning also let the students to study in advance } \\
\text { about the topic to be discussed in class because the topics } \\
\text { has clearly demonstrated and explained through the app. } \\
\text { Besides, students can create a forum to discuss any topics } \\
\text { related to the subject. }\end{array}$ \\
\hline $\begin{array}{l}\text { Assessment is through } \\
\text { answers. }\end{array}$ & $\begin{array}{l}\text { Assessment includes student works, observations, and point } \\
\text { of views, as well as tests. Process is as important as product. } \\
\text { Assessment is based on discussions in class. Any information } \\
\text { will be shared through the app where share option is } \\
\text { available on it. It depends on lecturer's creativity to make } \\
\text { the assessments vary. However, for certain circumstances, } \\
\text { the class still comprehend with the traditional method. }\end{array}$ \\
\hline Knowledge is seen & $\begin{array}{l}\text { Knowledge is seen as dynamic, ever changing with our } \\
\text { experiences. } \\
\text { Interactive tools and devices, motes on AAREAL make the } \\
\text { class more active with the participation of students } \\
\text { physically and virtually. It can be demonstrated through AR } \\
\text { version of classic animation devices in the app. Students are } \\
\text { able to scan the pictures of the devices and transform it into } \\
\text { interactive devices on app, which can be manipulated by } \\
\text { sense of touch. }\end{array}$ \\
\hline Students work primarily alone. & $\begin{array}{l}\text { Students work primarily in groups. } \\
\text { In order to explore the app, students tend to work in group } \\
\text { and in fact, it is more fun to work for it in group. In this case, } \\
\text { AAREAL app encourages students to work more in group by } \\
\text { providing activities and forums, primarily interactive and } \\
\text { dynamic. }\end{array}$ \\
\hline
\end{tabular}

Table 1: Difference between Traditional Classroom and Augmented Reality Classroom

\section{Conclusion}

This study reported the result of augmented reality (AR) implementation in history class through constructive learning method. The result has shown positive outcomes on elements of discovery, collaboration, scaffolding and self-guided learning. All of the elements were supported together to 
INTERNATIONAL JOURNAL OF ACADEMIC RESEARCH IN BUSINESS AND SOCIAL SCIENCES Vol. 10, No. 8, 2020, E-ISSN: 2222-6990 @ 2020 HRMARS

achieve active class learning. The emergence of AR as a learning tool was encouraging among educational expert and became as additional value through emerging technology in learning. AAREAL has helped students to explore interactive contents such as multimedia and 3D interactivity, thus has drawn attention and stimulate students' curiosity. In the meantime, it helped to increase the engagement in intellectual learning process. AAREAL also created a new learning environment that encouraged students to collaborate, retain and transfer the knowledge to real life. AR became a new platform for students to interact and experience the content which related to the real world. The changes of learning environment creates more conducive learning and different mood, besides enhancing emotional engagement such as positive feeling, optimist and excited about learning. Furthermore, this method of learning can be used in other subjects in different fields as to inspire teaching and learning interest, and foster creativity and teamwork spirit. Through AAREAL, students not only can interact and experience the content but also able to share their knowledge and experience through forum and discussion in social media, therefore will encourage the social engagement. This contribute to Zone of Proximal Development (ZPD) and can be achieved through testing on knowledge or understanding on the subject. Hence, training process, including various aspects of technology knowledge, pedagogy knowledge, and content knowledge should be coherently interwoven into the teaching and learning process so that students are sufficiently prepared for technology-aided education in the future.

\section{References}

Antonioli, M., Blake, C., \& Sparks, K. (2014). Augmented Reality Applications in Education. The Journal of Technology Studies,40(1/2), 96-107. Retrieved from http://www.jstor.org/stable/43604312

Bada, S. O., \& Olusegun, S. (2015). Constructivism learning theory: A paradigm for teaching and learning. Journal of Research \& Method in Education, 5(6), 66-70.

Bloom, B. S. (1956). Taxonomy of Educational Objectives: The Classification of Educational Golas. Handbook 1; Cognitive Domain.

Bereiter, C. (1994). Constructivism, Socioculturalism, and Popper's world 3. Educational researcher, 23(7), 21-23.

Chao, P. Y., \& Chen, G. D. (2009). Augmenting paper-based learning with mobile phones. Interacting with Computers, 21(3), 173-185.

Craig, A., \& Mc Grath, R. (2007). Augmenting Science Texts with Inexpensive Interactive 3D Illustrations.

De Freitas, S., Rebolledo-Mendez, G., Liarokapis, F., Magoulas, G., \& Poulovassilis, A. (2010). Learning as immersive experiences: Using the four-dimensional framework for designing and evaluating immersive learning experiences in a virtual world. British Journal of Educational Technology, 41(1), 69-85.

Dunleavy, M. (2014). Design principles for augmented reality learning. TechTrends, 58(1), 28-34.

Guion, L. (2002). Triangulation: Establishing the Validity of Qualitative Studies. http://edis. ifas. edu.

Harbison, T., \& Waltzer, L. (2013). Toward Teaching the Introductory History Course, Digitally. In Dougherty J. \& Nawrotzki K. (Eds.), Writing History in the Digital Age (pp. 97-109). Ann Arbor: University of Michigan Press. Retrieved from http://www.jstor.org/stable/j.ctv65sx57.13 
INTERNATIONAL JOURNAL OF ACADEMIC RESEARCH IN BUSINESS AND SOCIAL SCIENCES Vol. 10, No. 8, 2020, E-ISSN: 2222-6990 @ 2020 HRMARS

Joshi, R. (2019). Scaffolding in education: Promotes cognitive learning. [online] The Himalayan Times. Available at: https://thehimalayantimes.com/opinion/scaffolding-in-education-promotescognitive-learning/ [Accessed 7 May 2019]

Kaufmann, H. (2003). Collaborative augmented reality in education. Institute of Software Technology and Interactive Systems, Vienna University of Technology.

Kesim, M., \& Ozarslan, Y. (2012). Augmented reality in education: Current technologies and the potential for education. Procedia-Social and Behavioral Sciences, 47, 297 e302.

Klopfer, E., \& Sheldon, J. (2010). Augmenting your own reality: Student authoring of science-based augmented reality games. New directions for youth development, 2010(128), 85-94.

Kühl, T., Scheiter, K., Gerjets, P., \& Gemballa, S. (2011). Can differences in learning strategies explain the benefits of learning from static and dynamic visualizations? Computers \& Education, 56(1), 176-187. Elsevier Ltd.

Lindgren, R., Tscholl, M., Wang, S., \& Johnson, E. (2016). Enhancing learning and engagement through embodied interaction within a mixed reality simulation. Computers \& Education, 95, $174 \mathrm{e} 187$.

Mvududu, N. H., \& Thiel-Burgess, J. ( 2012). Constructivism in Practice: The Case for English Language Learners. International Journal of Education, 4(3), p108-p118.

NME. (2006). Elementary school social sciences course (6th Grade Instruction Program and Guide, National Libraries Directorate, Ankara).

Oh, S., \& Byun, Y. C. (2012, May). The design and implementation of augmented reality learning systems. In 2012 IEEE/ACIS 11th International Conference on Computer and Information Science (pp. 651-654). IEEE.

Oliver, K. M. (2000). Methods for Developing Constructivist Learning on the Web. Educational technology, 40(6), 5-18.

Skinner, B. F. (1953). Science and human behavior, New York: The Macmillan Company.

Schrier, K. (2006). Using augmented reality games to teach 21st century skills. Paper presented at the ACM SIGGRAPH 2006 Educators program.

Sze-Yeng, F., \& Hussain, R. M. R. (2010). Self-directed Learning in a Socioconstructivist Learning Environment. Procedia-Social and Behavioral Sciences, 9, 1913-1917.

Taketa, N., Hayashi, K., Kato, H., \& Noshida, S. (2007). Virtual Pop-Up Book Based on Augmented Reality, 475-484.

Tam, M. (2000). Constructivism, instructional design, and technology: Implications for transforming distance learning. Journal of Educational Technology \& Society, 3(2), 50-60.

Ulusoy, K., \& Gulum, K. (2009). Teachers' material use in social sciences lectures during history and geography topics are taught. Journal of Faculty of Education, c.10, 2, 86, 85-99.

Van Krevelen, D. W. F., \& Poelman, R. (2010). A survey of augmented reality technologies, applications, and limitations. International journal of virtual reality, 9(2), 1-20.

Wagner, D., Schmalstieg, D., \& Billinghurst, M. (2006, November). Handheld AR for collaborative edutainment. In International Conference on Artificial Reality and Telexistence(pp. 85-96). Springer, Berlin, Heidelberg (pp. 85-96).

Wu, H. K., Lee, S. W. Y., Chang, H. Y., \& Liang, J. C. (2013). Current status, opportunities, and challenges of augmented reality in education. Computers \& Education, 62, 41-49. 